\title{
A Case Study Approach for Managing Risks \& Challenges When Expanding to Emerging Markets
}

\author{
Evangelia Fragouli ${ }^{1} \&$ Zoi Nikolaidou ${ }^{2}$ \\ ${ }^{1}$ School of Business, University of Dundee, Dundee, UK \\ ${ }^{2}$ Hellenic Open University, MBA, Greece \\ Correspondence: Evangelia Fragouli, School of Business, University of Dundee, Dundee., DD1 4HN, UK. Tel: \\ 44(0)-1382-385772. E-mail: e.fragouli@dundee.ac.uk
}

Received: December 2, 2019 Accepted: December 14, 2019 Online Published: December 27, 2019

\begin{abstract}
Globalization created new opportunities and many companies decide to expand to take advantage of these opportunities to improve their competitiveness. The present study, using a case study methodology, examines the expansion of three large companies (IKEA, Coca Cola and Kellogg's) in emerging markets. Through a critical literature review and review of corporate reports, the study analyzes companies' adopted strategies and practices, influential factors and risks when expanding abroad, providing the rationale behind their strategic choices. The study findings, applying theory into practice, indicate the factors and practices that are important to be considered by companies operating in a foreign environment in order to address business risks, and concludes that in order to be successful they have to incorporate into their strategy effective risk management policies to mitigate risks and turn challenges into opportunities. The study bridges risk management and strategy development.
\end{abstract}

Keywords: strategy, expansion, emerging markets, risk, challenge

\section{Introduction}

Globalization has greatly affected the interaction between economies; it has reduced the economic barriers for enterprises and it has encouraged the operation of multinational companies. As multinational companies are the companies with the greatest potential, many companies, including SMEs, are looking to internationalize their activities in order to become viable in the global environment. However, internationalization is a complex and risky decision for firms, which undertake greater risks, as they operate in a more uncertain environment.

Strategy development in foreign markets has been an interesting research topic since the rise of globalization. When an organization plans to enter a foreign market, there are a variety of decisions to be made, such as the entry mode (Sarkar \& Cavusgil, 1996; Hill, 2007). An organization planning to function globally faces issues, such as: marketing, sourcing, investment and control (Johnson et al.,2008). Most researchers consider mode of control (Hill et al., 1990) resource commitment requirements (Vernon, 1983) to be the most important decisions that a company has to make when entering a new market. This study will also examine other factors, related to the features of the country, which should also be taken into consideration, as they can affect the company's market share in the new market. These factors are not adequately examined, using case study methodology, so the current study contributes to the presentation of their recognition by specific companies.

The aim of a company's decision to enter a new market is to increase its profit on sales, to find new resources, new markets, build new strategic capabilities (Dunning, 1993). The development of new markets is thought to be the most important reason for internationalization (Floyd, 1996; Mayer, 1995; Ruzzier et al., 2006; Ramamurti, 2012). But there are a great number of complex decisions that need to be made in order for the internationalization to be successful, such as market selection, market entry, strategy formulation and implementation. Moreover, an entry strategy is essential for each product and each market the organization plans to enter (Root, 1994). Businesses operating in several countries face a number of challenges. As globalization is a complex and risky decision for a company, the study will examine the risks and opportunities and the practices followed by companies, so as to enable them to internationalize successfully, focusing on emerging economies. As most global companies come from developed countries, the study will focus on them.

When a company decides to enter a new market, it has to consider its main strengths and weaknesses, but it should also evaluate the opportunities and threats of the external environment (Prahalad \& Hamel, 1990). In order to 
examine the opportunities and risks of a new market, managers may use market growth and other rations referring to the market (Kumar et al., 2004) but also factors affecting its adaptation costs, such as cultural aspects (Wood \& Robertson, 2000). Many companies decide to enter markets with great potentials as shown in quantitative factors, such as the Chinese and the Indian market which have a great size and very high market growth, but fail to capture more qualitative aspects, such as cultural differences. This may have a great negative impact on their market entry. The current study examines three cases where companies entered the Chinese and the Indian market, without being fully aware of the market's environment, so, they had to re-examine their practices.

\subsection{Research Aim and Objectives}

The aim of this study is to explore how companies from developed countries are managing opportunities and risks as they enter emerging markets and also to explore the practices they use to become successful (in terms of market share and profitability) in the new environment. So, the study examines the practices of companies operating in emerging economies and the way they manage their risks.

\subsection{Research Questions}

Based on the above scope and objectives, the main research questions required to be answered in this study are the following:

Research question 1: What practices are followed by the selected companies to become active in emerging markets? Research Question 2: How do the selected companies manage the risks of entering an emerging economy?

Research question 3: Which are the factors that should be taken into consideration when entering an emerging market?

Research question 4: What are the risks and challenges companies deal with when entering emerging markets? How globalization and the characteristics of the markets increase or minimize these risks and challenges?

\subsection{Methodology of the Study}

The methodology used in this study is case study. This methodology is appropriate, since only a small number of companies is examined for their practices when entering an emerging market. Three companies are selected and these are Coca Cola, IKEA and Kellogg's as they have globally known brand names, they come from developed countries and they represent different sectors, so they can offer an insight in the practices used by different sectors, thus comprising an indicative sample.

The examined variables for the three selected cases are their market share and business performance in order to find out the ways they were affected by the practices used for entering into foreign markets.

\section{Literature Review}

\subsection{Going Abroad: Issues to be Considered}

Global industries consist of companies whose competitive position in a national market is affected by the competitive position they have in other national markets, so they have to formulate a global strategy (Ghoshal, 1987; Prahalad \& Bhattacharyya, 2011) which differs from the corporate - level strategy, business - level strategy and strategic business - strategy. A global strategy is a corporate level strategy because it refers to the overall direction of the company, such as geographical coverage, diversity of products and decisions about the way resources are allocated between business units (Johnson et al., 2008). A global strategy is risky and complex even for the largest companies in the world. So, it is critical for companies to adopt a strategy that treats decentralization and centralization as complements. (Prahalad \& Bhattacharyya, 2011).

Analysis of the environment market selection and market entry are important factors to be considered before any decision be made regarding development of a strategy for expanding abroad. The impact of globalization, has increased interdependence between economies (Hamel \& Prahalad, 1986) and global organizations have to deal with domestic forces of host countries they operate in (Ball et al., 2004). The organization needs to precede environmental audit in order to evaluate the external environment and its competitive features, to select, to select the specific market deciding if can either :(1) penetrate in the existing market, (2) develop new products for the existing market, (3) develop new markets for the existing products, or (4) diversify in new markets with new products. (Johnson et al., 2008) and to find out which is the best way to enter the market (Johnson et al., 2008).

\subsection{The Practices and Strategies for Entering Emerging Markets and Their Effectiveness}

Top management of western multinational corporations are aware that globalization is the most critical challenge they have to face, so they have to develop international strategies (Khanna et al., 2005). More specifically, emerging countries show challenges and opportunities for global companies, as they include a large number of 
potential customers and only a few competitors, so they offer great opportunities for profits (Prahalad, 2006). But, these markets are more uncertain (Khanna et al, 2005). So, when a company identifies opportunities in an emerging market, it has to make sure it has the necessary capabilities to take advantage of them (Johansen, 2014).

The financial crisis of 2007 increased economic uncertainty and led many companies to review their strategies, so as to have a longer-term focus, which serves all of a firm's stakeholders rather than just shareholders. (Witcher \& Chaw, 2012). Deloitte (2014) conducted a survey for the prospects of globalization. The main practices proposed for expanding in an emerging market are the following:

- Engagement with local communities for recruitment and collaboration with locals. There are talents in these markets that can be significant resources for the company

- External partnerships are crucial for achieving innovation. These partnerships can share their know-how for the production of the products and also for the prevailing conditions in the market.

- The companies should have in mind social impact issues, concerning worker rights, improving the local community and local infrastructure and environment.

- Social business tools, such as collaboration with customers and real time information, are very useful in emerging markets. These tools can be obtained through the social media.

- Greater protectionism in policies followed in emerging markets is more intense, so this has to be taken into consideration.

- There are more supply chain challenges, as it more difficult to access supply chain capabilities in emerging markets.

- Global issues have to be addressed with local solutions. This practice can be implemented with local market research, customized strategies, joint ventures with local companies, partnership with government, local $\mathrm{R} \& \mathrm{D}$, employment of local vendors and talents, design of products suitable for local customers and transfer of managers from the headquarters at the host country.

Companies in developed countries are used to having infrastructure available for the execution of their business models in their home markets, but infrastructure is usually underdeveloped in emerging markets. Moreover, in emerging countries companies can't find market research companies to get information for the market it considers entering. There is also lack of logistics providers and human resources firms to screen large numbers of candidates. Because of all those institutional deficiencies, multinational companies perform poorly in developing countries. This is the reason why many CEOs are avoid emerging markets and prefer to invest in developed countries. (Khanna et al., 2005). So, companies can achieve success in an emerging market if they fit to their environments, if their top managers take rapid decision and are capable of gaining knowledge on the new market and of building the necessary capabilities to manage the risks and the opportunities of the emerging markets.

This process should include a thorough understanding of each market infrastructures. Multinational organizations take into consideration either the macro factors (openness and sociopolitical environment) or market factors, but only a few of them examine both. Referring to political and social factors, every country's political system has an impact on its market, while the country's social environment is significant as well. The relationships between ethnic, regional, and linguistic groups a market may also affect the market entry decision. Referring to openness, economies need to be open in order for companies to enter, because they welcome direct investment. The two macro contexts determine the market contexts. Accordingly, market analysis includes product markets (as companies try to get reliable information about consumers), labor markets (multinational companies have difficulties recruiting skilled personnel, as the quality of human resources is difficult to ascertain), capital markets (financial markets in developing countries lack of sophistication and reliability) (Khanna et al., 2005).

Emerging markets are now viewed as sources of new consumer demand, and not just low-cost production hubs. Moreover, emerging markets are getting more familiar, as nearly half of the companies have been operating in emerging markets for at least a decade, while and two-thirds have been operating there for at least six years. In order to enter successfully an emerging market, companies look for partnerships and alliances with local companies because of the need for local knowledge and contacts.

Deloitte Consulting (2011) conducted a survey of 628 executives to examine revenue opportunities in emerging markets. The results showed that success in emerging markets did not come from establishing a sales office for their existing products, but the companies had to understand the preferences of customers in each market and design a strategy to meet their needs at appropriate prices. The research identifies three features of successful growth strategies. The first one refers to locality. The second is organic growth for expanding in emerging markets 
followed by joint ventures with local companies. The third important key for success is adapting to the market. Companies have to customize their offerings to local customers' needs, by designing products specifically for the local emerging market and offering a different value proposition. So, the results of the survey show that successful strategies include local operations, organic growth and adapting to the market. (Deloitte, 2011). These results are in accordance with Taneja et al., (2012) and Deloitte (2014).

Boston Consulting Group (2013) conducted a survey in more than 150 top executives in order to understand their priorities and their performance in emerging markets. The results showed that the success factors are the following: top management support, local talents, market knowledge, and a broad range of capabilities. The survey concludes with a checklist, which can guide companies to enter an emerging market. According to this, the companies should: 1) Identify opportunities, set priorities and specific targets. 2) Identify their strengths and weaknesses, 3) Develop and test their business model, in order to identify changes that need to be made, 4) Develop relationships with stakeholders and analyze the local environment for potential mergers and acquisitions, joint ventures and other types of market entry, 5) Assess and evaluate their workforce, set training programs and find potential rising stars in the emerging markets, 6) Set emerging market issues on agenda of top management, hold meetings with stakeholders, locate managers in the emerging markets, create incentives for the success in emerging markets and make sure that the managers have the skills for adaptation, forecasting and best-practice sharing.

\subsection{Managing Risks and Global Strategies}

A global strategy requires adaptation of the company's risk practices, as environmental uncertainty rises. Most companies focus on risks before they enter the market, but they tent to underestimate the risks that come after the entry, a fact that leads to the underestimation of new threats that were not present at the time of the entry, so business leaders must constantly re-adjust their risk management strategy (PwC, 2012).

Lassar et al. (2010) support that a company's risk management strategy consists of three factors, the resources it uses, network systems and performance criteria. Ernst \& Young (2007) undertook a survey for risk management in emerging markets. The findings suggest that two thirds of developed and emerging market companies aim at growing and taking advantage of the market potential of the country itself and so, emerging markets are still dynamic. Referring to risk management, companies in developed markets put emphasis on political, operational and supply chain risk, while companies in emerging markets focus on market and competitive risk, currency, workforce, pricing and tax risk. Moreover, companies in emerging markets emphasize on market and currency risk. About their risk management approach, there are some common practices that take place, but no clear framework, so there is overall room for improvement. The practices followed that have to be improved are the following: a deeper understanding of the market, the consideration of local expertise, partnerships, understanding local laws and culture, communication, flexibility to the changing conditions of the environment, and long-term thinking.

Many researchers examine the relation between internationalization strategy and risk. Anil and Cakir (2010) suggest that when companies know better the similarities between the business styles and the local culture of the host country, they choose joint ventures. Moreover, uncertainty can affect the selection of the entry mode. Whollyowned Subsidiaries are preferred when uncertainty makes contracts ineffective and leads the partners to delays (Brouthers \& Hennart, 2007). Another aspect is the company's previous experiences in the host country or internationalization, as companies with significant international experiences would prefer wholly owned subsidiaries because they are less in need of local partners (Dikova \& Wittelloostuijn, 2007). Meyer et. al., (2009) note that firms which enter emerging markets prefer to use joint venture when the institutional conditions are weak. Accordingly, when the institutional environment is stronger, they prefer acquisition strategy. Several researchers (Wright et al., 2005; Meyer \& Peng, 2005; Brouthers \& Hennart, 2007) note that there are many factors that affect companies' decisions, especially in the emerging markets, so it is difficult to explain the strategies of international companies with the use of only one theory. Dunning's Eclectic Approach can be useful, as it covers many theories (Brouthers \& Hennart, 2007).

Development of a strategy for entering an emerging market and risk management should be interrelated. Companies have to set a coherent strategy related to the external environment, in order to exploit its opportunities, but the riskier the strategy the more it should focus on risk management. Accordingly, they have to design an effective risk management framework that fits the strategy. The strategy and risk management framework need to be constantly adapted to fit the changes, while more resources have to be invested in their function (Olsson, 2002). Global activities can cause many benefits to organizations, but it can also expose them to a number of risks. Martin et al. (2011), find that most companies do not have a structured risk management system, but instead they use a number of informal approaches to cope with risk. So, there should be a multidisciplinary approach when dealing 
with global sourcing risks. In that case, risks are divided in four categories: supply risk, process and control risks, environmental and sustainability risks, and demand risks.

\section{Research Design}

\subsection{Case Study Methodology}

The methodology used in this study is case study. Case study methodology is widely used in social sciences (Yin, 2003) providing a deep insight in complex cases (Vissak, 2010) and actual conditions following a qualitative analysis (Dul \& Hak, 2008). Moreover, it has the advantage to analyze the historical background and the socio cultural context of a particular case (Stake, 2000), explore applications of theories (Iacono et. al., 2011) and influential variables (Johansson, 2003). Data analysis is qualitative because it helps the understanding of the background of the examined cases (Richie \& Lewis, 2003), setting them in their natural environment so as to interpret their actions (Denzin \& Lincoln, 2000).

\subsection{Sample Selection}

The analysis will include three cases, which are Coca Cola, IKEA and Kellogg's. These three companies are worldwidely known multinationals and they are leaders in their industries, thus they can be considered successful, in terms of reputation and profitability. Moreover, they all are consumer product companies, they all are multinationals with big size. Coca Cole is the best-known brand in the world and is present in most countries, being the leader of non-alcohol beverages and representing a specific way of life. IKEA is the largest furniture retailer worldwide, which became well-known for its philosophy and strategy. Kellogg's is a famous breakfast cereal company, with a successful presence in many countries of the world. All three of them, however, faced problems when they entered emerging markets, and they managed to overcome the obstacle and finally succeed.

\section{Presentation of the Cases}

\subsection{IKEA}

The main challenge the company faced in its global strategy was its entry to the market of China in 1998 . According to Treadgold (1991), global retailers, including IKEA tend to have low local responsiveness and adaptation. IKEA has the principle to operate similarly and have the same image in all countries. This choice helps the company to keep the price low and its products affordable for as many people as possible. Its marketing strategy comprises of the following parts (Burt et al., 2008):

- The most important part of the company's marketing strategy is the product, along with the price, which is generally expected to be the same or only slightly altered, everywhere. The prices are required to be low in comparison to the competition, so the consumers can enjoy high value at low price.

- The location of IKEA stores is on the outskirts of large cities so as to be easy to park, as most consumers use the car for their transportation. Stores are also standardized and only vary in size, as they come in three different sizes. IKEA's promotion has the catalogue in its core, a means that is unusual for a retailer. This is the most important marketing tool the company uses, and it absorbs nearly $70 \%$ of the annual marketing budget.

\subsection{Kellogg's Case}

Kellogg's is a multinational food production company, one of the best known global brands and the world's leader in cereals. Its breakfast cereals are being sold in 160 countries. But, despite its worldwide success, Kellogg's faced problems when entered the Indian market. On its initial entry, Kellogg's kept the same marketing mix that it used in other markets, with minor changes. When the company entered the Indian market in 1994, it attempted to change the Indian cereal market by altering the breakfast habits of Indian consumers. Indians were used to hot breakfast choices. Moreover, the consumers' habits changed from region to region. Kellogg's desired to persuade the consumers to instantly switch from their traditional habits to healthier breakfast cereals (Taneja, 2012). This aggressive practice affected in a negative way the consumers. So, Kellogg's had to find a new strategy for India.

More than a decade after its first entry to the Indian market, Kellogg India started exploring new formats of cereal consumption, category segmentation and localization too beat its competitors in the cereal market which is slowly rising. Kellogg India also relaunches muesli brand Extra and plans capacity expansion at its Taloja plant (Bhushan, 2008). In 2012, Kellogg India tried to localize its portfolio and started rolling out variants like pudina, tomato and garam masala for its oats range (Bhushan, 2012). The opportunities are still huge in cereal and overall breakfast segment in India, because penetration is still very low. The company created a new market in India and in the last 5-7 it invested in building a large portfolio of innovative products made to fit the Indian taste and needs. This is still the company's biggest challenge, although now it has more competitors to beat (Anand, 2014). 


\subsection{Coca Cola Case}

Coca-Cola is the leader of the beverage market worldwide. Although the company had entered most of the countries of the world, it met significant difficulties, when it entered the Indian market (Forbes, 2015). The company initially entered the Indian market during the 1970s, but it was forced to exit by the Government. So, Coca Cola re-entered the Indian market in the 1993 after the political environment was more advantageous and liberalized the market. But, the company failed for many years to realize profits due to its aggressive strategies, such as promotion and pricing in its attempt to beat the competition (Taneja et al., 2012). Coca Cola also suffered because of the pesticides controversy which happened in 2003 and greatly affected its sales and its brand image in India (Mukherjee, 2008).

So, although Coca Cola is one of the largest companies in the world and a global leader, it faced problems with its strategy, when entering an emerging market. The main threat came from the political and cultural environment, as its practices were considered to be very aggressive. Its multinational 'ego' let Coca Cola use practices designed in the headquarters and not in India. But Coca Cola has the opportunity to increase its market share in India, by promoting its iconic brand Coca Cola, as since now it's a local product 'Thums Ups' that makes the company the leader on the market (Jaganathan, 2013).

\section{Analysis of the Cases}

\subsection{Ikeas Strategy}

IKEA's strategy when it started to expand in Scandinavian and other European countries did not focus on local tastes and preferences in each country, so, only necessary changes were made by the company, so as to keep cost low. IKEA's internationalization was successful in Europe, despite the low responsiveness to local needs. Wholly Owned Subsidiaries were chosen because IKEA was not in need of local partners (Dikova \& Wittelloostuijn, 2007) But when the company decided to enter other markets, such as China, this has led to the emergence of global strategic management. In this case, a combination of strategic management and international business strategy was needed to enter the market and surpass the obstacles due to environmental and cultural differences (Twarowska \& Kakol, 2013). IKEA used different strategies, as some of the stores in China are wholly-owned subsidiaries, while others are joint ventures with local companies. This was due to the fact that IKEA recognized the uncertainty and the cultural differences (Meyer et. al., 2009). This choice reduces risk, as the cost is lower, and furthermore, local companies have better awareness of the market conditions. Its employees and most of the managers are local, in order to fit the local culture, when serving the customers and designing their next moves.

In China, IKEA had to focus on more specific target groups than usually. Moreover, it targeted different groups of people in comparison to its practice in other countries. IKEA's target group in China is a group of the population, which is called 'the little emperors'. They are the generation which was born into the One Child Policy and they are now around 20-30 years old. This segment of the market consists of nearly 30 million people. They are impulsive, easy to influence, social and prefer well know foreign consumer brands. As the salaries tend to increase in China, the size of this market segment tends to increase every year (Burt et al., 2008).

The company had to change some parts of its strategy to succeed in the Chinese market, such as the following (Burt et al., 2008):

- Product: Another problem IKEA had to face in China was copying of its products. It is a frequent phenomenon for Chinese shoppers in IKEA to draw pictures of the furniture and taking notes on the descriptions of the products, but not buying them. It is a fact in China that many local companies copy and sell IKEA-like products, even in lower prices.

- $\quad$ Price: The basis of IKEA's strategy is to be perceived as having low prices, but this goal was not achieved in China, where IKEA is seen as a western retailer for the higher middle class. This impression may be due to the fact that imported products are subject to import taxes $(22 \%)$. So, in order to reduce its prices, IKEA China started sourcing of products in China.

- Place: An adaptation that had to be made by IKEA in China are the stores, which are located closer to city centers, as most consumers do not have cars. IKEA tries to build the room settings in a more Chinese way, so as to look realistic. In general, the shopping experience is different, because stores are considered to a social area, for the Chinese. Another different consuming pattern in China that the company had to take into consideration is the fact that customers buy less in each visit, but they visit IKEA more often than anywhere in the world. This fact has an implication in the organization of the stores, as there is a need for frequent changes. 
- $\quad$ Promotion: IKEA created many ads in China and the themes are the same as in the rest of the world, but with some adjustments to fit the Chinese attitude. There are more humble and friendly home solutions; there is an attempt to educate the consumer etc. Another difference refers to the promotion mix of the company. In China, the reliance on the catalogue is much smaller as it is not economical to distribute it, so the catalogue is distributed in the stores. But, at the same time the company distributes smaller brochures. Moreover, IKEA uses public relations in China. For example, the company transformed the interior of 20 elevators in less affluent residential districts in Beijing, to show that change may be easy. Another example of public relations is a TV-show where the viewers are offered lessons in home decorating.

So, it is obvious that IKEA had to adjust its basic principles in China, in order to succeed in this market. The principles that made IKEA well-known is the fact that customers have to carry the products and set them themselves, its prices are low, all stores have the same format etc. The company learnt many lessons in China. The company could not use the same practices and strategies in every market. It has to keep tight some areas, such as brand name, communication, store concept, but it should also adjust some other parts to be relevant on the market. The issues that had to be changed were the following: prices, service in the shops, the organization and decoration of the shops, so as to be more familiar to local customers, and more friendly, as Chinese go to shopping to socialize (Burt et al., 2008).

Another significant factor is the issue of application of risk management. The case of home furnishings retailer IKEA, can show how risk can be considered as the cost of entering to new markets, as part of a global operating model. IKEA gets its products from 1,600 suppliers in 55 countries, an option which increases operational and reputational risks. However, IKEA was not economical to produce its very large portfolio of products without its suppliers. In order for the company to maintain quality and safety standards, IKEA has created a "responsible supply chain program". According to this, there are a number of formal processes which ensure that all suppliers produce goods compliant with internationally recognized standards. Furthermore, external auditors regularly monitor this supply chain network. So, IKEA manages risk by implementing operating standards on a global level (PWC, 2009).

IKEA's idea for developing relationships with suppliers lies in its strategy of producing low price products, in a socially and environmentally responsible way. So, suppliers have to fulfill some strict requirements. When the company enters a new market, it has to pick up its suppliers very carefully. For example, in Russia, the executives of the company had to search in personal level all the suppliers and partners, in order to avoid mistakes (Tarnoskaya et al., 2007). So, in China as well the company had to carefully select its suppliers, in order to provide quality material and products, in a responsible way. Moreover, personal relations with them offers the company the opportunity to know how Chinese think and do business. One third reason for this approach to be applied is the fact that local suppliers make consumers think positively of the company, and it is easier to fit the local environment, because they already know its partners.

\subsection{Kellogg'S Strategy}

Kellogg Company entered the Indian market in 1994. Kellogg decided to enter the Indian market using Foreign Direct Investment, and more specifically, a wholly-owned subsidiary. This is a risky decision as it entails a large investment, but the company selected it, as it wanted to keep the control. This selection was made as the company had previous international experience, so it thought it would not need any partners (Dikova \& Wittelloostuijn, 2007). The company entered the market with a product mix, comprising of cornflakes, wheat flakes and Basmati rice flakes. The products did not have a warm reception in India, despite continuous managerial, financial and technical support by the mother company. The basic problem was the product itself, as the idea of eating cornflakes for breakfast was not easy to imagine for the Indians, who would prefer hot vegetables for breakfast. Moreover, the Indian consumers were used to having hot milk for breakfast, but hot milk made the flakes soggy (Fernandes, 2013). So, Kellogg's did not know the different local culture well enough and there could have been a joint venture (Anil \& Cakir, 2010).

India was a difficult market for Kellogg's to enter, as the company had to change the eating habits of the consumers. It finally managed to become the leader in breakfast cereal category in the country, and now the company has almost 60-65 percent of India's market share. This new product category was difficult to be adopted in India, as food habits change from region to region (Shukla, 2011). In its first advertisements, Kellogg's claimed that Indian breakfast was not healthy, but their approach offended the Indians who had been serving it to their families, so they did not buy Kellogg's as a response. Moreover, Indian breakfast was cheaper than Kellogg's corn flakes. So, it was difficult for Kellogg's to persuade Indians to abandon their traditional food and choose cereals. Furthermore, 
Indian consumers preferred warm milk, while corn flakes are better with cold milk, in order to remain crispy (Taneja, 2012). So, the company had to find new strategic solutions to become successful in the Indian market.

In this hostile environment, Kellogg's adjusted its strategy and proceeded to new product development of wheat and rice cereals. The new products had flavors which were familiar to the Indians and compatible to their local habits. The company launched Chocos wheat scoops coated with chocolate and Frosties with sugar frosting, in an attempt to indianize its products. The company finally had a successful entry in the Indian market, after taking into consideration of the local tastes. Gradually, the breakfast routine altered with the new products, and the demand for cornflakes started to grow as well. So, the key of success in this case is the fact that Kellogg's realized that the American culture would not be accepted in this country and decided to adapt and modify its strategy in India (Fernandes, 2013).

Kellogg's experience in India shows that even the most successful companies in the world face significant risks, when entering an emerging market, especially one that is culturally different than the home country of the company. The company learned some very important lessons from its mistakes in the Indian market, so Kellogg's took over some totally different marketing initiatives, which were specialized for the Indian market, in order to build its brand name in this market. One of the problems it faced was the high price of its products. In order to solve this problem, it launched small sized pack. For their advertisements, they took advantage of the Indians' love for Hollywood superstars, such as Spider man (Taneja et al., 2012).

As refers to packaging, it was used as a tool for communication with consumers, as it helped for the on-shelf differentiation from competitors products. Kellogg's also promoted its brand name as socially responsible, through recycling and reusing materials, improving the access to health and many more. All these changes were especially designed for the Indian market. There were also some alterations to the products and launched the sugar coated Froasties and Chocos Wheat Loops coated with chocolate, because Indians wanted their food to be tasty. For the women, Kellogg's launched a new product Kellogg's Special $K$ and selected Lara Dutta (which is a famous in India Bollywood actress) as their brand ambassador (Taneja et al., 2012).

Referring to pricing, the company had to reduce its costs in order to be able to become affordable for Indian customers. This became possible with the localization of raw material and packaging material. Kellogg's also set up new manufacturing facilities in India to reduce the overall transportation costs and to increase its presence in the economy. All these adjustments to the company's strategy made it possible for the company to reposition its brand and gain around 60-65 percent of the market share of the breakfast cereals market (Taneja et al., 2012).

The above issues refer to business-level and business unit-level strategies, although global strategy was mentioned to be corporate level-strategy. To be more specific, the decision to enter a new market and expand the product portfolio of the company are part of the corporate strategy. On the other hand, the competitive strategy that will be applied by the specific business and the marketing decisions are parts of business-level and business unit level strategies, accordingly.

Another function of the company that needs to be addressed is its risk management strategy, which has to be embedded to its global strategy. The company faces many risks and uncertainties, which may adversely affect its business and financial condition. The risks the company faces are the following: Market risks (foreign exchange risks, interest risk, price risk), credit risk. As Kellogg's has a significant global presence, it faces some additional risks, such as political risk, and market risks. Market risks are affected by the conditions that prevail in the markets it operates, and include foreign currency risk, interest rate risk and so forth (Kellogg's Annual Report, 2014).

The company recognizes that the results of the company may differ from their predictions, due to a variety of reasons, such as the competitive conditions, the effectiveness of its pricing, advertising etc, the success of innovation and new product introductions, the success of productivity improvements, the fluctuations of commodities and energy prices, disruptions in supply chains, fluctuations of interest rates and currencies, integration of acquired businesses, the effect of economic conditions, tax regimes, legal and regulatory factors for food safety, advertising etc., risks related to global operations, risk from specific emerging countries, even the ability to implement Project K effectively and with the proper cost (Kellogg's Annual Report, 2014). As the company is exposed to many forms of risks, it uses derivative instruments to manage these risks, but it does not proceed in speculative transactions. Referring to foreign exchange risk, the company is exposed to fluctuations in foreign currency cash flows which may be caused by third-party purchases, intercompany transactions etc. It is also exposed to fluctuations of foreign currency investments in subsidiaries and the cash flows related to repatriation of these investments (Kellogg's Annual Report, 2014). The above practices are common and normal, but Kellogg's designed a more integrative risk management framework, Project K. 
In order to be better protected by any risk, Kellogg's designed and launched its global four-year efficiency and effectiveness program, Project K, in 2013. This program's implementation has significant organizational and infrastructure challenges. Project $\mathrm{K}$ requires negotiations and collaboration with third parties, including labor organizations, suppliers, business partners, and other stakeholders. But, Project $\mathrm{K}$ is very complex and requires a large amount of management and operational resources, in order to implement the administrative and operational changes (Kellogg's Annual Report, 2014). This initiative is very important as it introduces a holistic approach to risk management and strategic management. The company increases monitoring in most of its operations, in order to be better protected and to function more efficiently.

Referring to the risks the company undertakes with its global strategy, the company acknowledges that emerging markets have greater political, economic and currency volatility and greater vulnerability to infrastructure and labor disruptions. In these countries, it may be common for others to proceed to practices prohibited by laws and regulations, such as anti-bribery laws. Moreover, competition in emerging markets increases as low cost local manufacturers get better. Project K covers these risks, as well (Kellogg's Annual Report, 2014).

\subsection{Coca Cola'S Strategy}

Coca Cola is the most recognizable brand in the world. The company sells more than 400 brands in 200 countries, as it has been expanding internationally for the last fifty years. The Coca-Cola Company also focuses on the quality of its products and social responsibility, in addition to brand recognition (Gomez, 2012).

Coca Cola had entered other emerging markets, such as China. When the company entered the Chinese market it faced the challenge of branding, because linguistics in Chinese changed the sound of the brand name and its meaning. At that time, more specifically in 1928, there was no official representation of the name in Mandarin Chinese, so the company had to find characters whose pronunciations were similar to the sound of the brand, without producing a negative meaning. After that, Coca Cola revised its name (Gomez, 2012).

Coca Cola decided to enter the Indian market using wholly-owned subsidiaries, a form of Foreign Direct Investments. This decision relied on the previous experiences in the host country (Dikova \& Wittelloostuijn, 2007). As the top management is conducted in the headquarters in the USA, the company recruited local managers and employees to localize its function. Coca-Cola's strategy can be described as "glocal", which is a combination of global and local. The concept of glocalization is the response to the problem posed from the fact that a genuine global strategy is considered to be a managerial utopia, so companies have to adjust to local conditions to be accepted in a new market (Svensson, 2001). Glocalization adjusts a standardized global strategy, by integrating local cultural characteristics into a company's strategy, so as to appear as social accommodating to the local market (Maynard \& Yan, 2004) With this strategy, Coca-Cola has a well known brand image and implements local practices, at the same time. Coca-Cola succeeded to understand and satisfy local markets' needs. Furthermore, the company has to create new products for each market. For example, in China, the Minute Maid Pulpy Super Milky drink and the Sprite Tea drink have been developed by the research and development unit in China and they are considered to be popular in the country (Gomez, 2012).

But the case that will be analyzed is the entry of Coca Cola in India. On October 24, 1993, Coca-Cola returned to India after 17 years. The company had left the market in 1977, when a newly elected government demanded that Coca-Cola had to partner with an Indian entity. The company refused and left its market leadership position. In the 1990s, India began to open up its economy to foreign investments, so Coca Cola designed a strategy to reenter (Moye, 2013).

Coca-Cola re-entered the Indian market in 1993 and continued to struggle until 2006 to be profitable there. The cultural fit of its strategy was the key that helped Coca Cola succeed in India, as the company found out that a single global strategy was not effective. So, there had to be an emphasis on local issues and culture. The brand localization strategy was had to divide the country into two main segments. The first segment represented metropolitan and larger towns. This segment prioritizes their social bonding. Te second segment of the Indian market includes small towns and rural areas which account for $96 \%$ of the total population. In this case, local language and idioms were appropriately used in Coca Cola's advertising campaigns Moreover, local employment and corporate social responsibility for community and environment made Indians accept the company (Fernandes, 2013). The above changes were made possible with the support of the top management, which decided to recruit local talents in India to gain awareness on the Indian culture.

In order to overcome the problems it faced in the Indian market, Coca Cola invested a large amount of money (around one billion US dollars) to construct and improve infrastructure required for succeeding in India. The company set-up 25 wholly owned bottling plants, in order to achieve a deeper level of penetration in the Indian market (Mukherjee, et al. 2008). 
The company also tried to reposition the Coca-Cola brand in the specific market. Initially, it had used global communications only, a choice that proved to be a mistake and it adapted its communication practices to be more appealing to Indian consumers. Global communications are advertisements and other promotion actions, which are the same globally and not specifically the Indian market. After the failure of this global approach, the company used the two most successful tricks in Indian advertisement, which were Bollywood and Cricket. Bollywood actors and cricketers were recruited to promote the brand and they succeeded in creating the mass appeal for the brand in India. In order to increase penetration in rural areas, Coca Cola also reduced the entry level price. Moreover, in its attempt to overcome the challenge Coca Cola faced in 2003 and the pesticide controversy, they hired Aamir Khan and Smriti Irani, who were very popular in India and filmed a commercial where Aamir is given a tour of the Coca-Cola factory and informed about the 400 quality control tests that are a part of the production process. So the consumers were convinced that the brand is safe. After the success of this communication strategy, Coca Cola managed to overcome the above challenges, and was again ready to expand in India (Taneja et al., 2012).

The company's worldwide operations have significant risks, so a risk management plan is necessary. Coca-Cola uses multiple tools to assess risk, such as data mining and analytics. The company is currently focusing on big data and how to manage information. According to its top management, the key activity in risk management is to prioritize the activities in which the company's resources will be invested (Deloitte, 2013).

Coca-Cola has established a process of discrete steps risk-management. The first step is the basic deployment of the process. In this stage, there is identification of significant risks, analysis, design of procedures for mitigating them, and the creation of a "risk register". Risk register is a document, which tracks the status of risk and its treatment for every business unit, group, bottler and corporate entity. This framework is based on ISO 31000:2009, which provides best practices in risk management. The main risks that need to be addressed are divided into 11 major categories: risks by contract, such as suppliers; liability; professional liability losses; environmental; crime and theft; damage to physical property; lost, delayed or damaged cargo; business interruption; trade credit; political risk, and risks to employees.

After the stage of identification, there should be focus on how to sustain the risk-management process. Coca-Cola uses the following approach: It reviews the risks that are being managed, it identifies new and emerging risks, and it incorporates the key risks into the planning process (Bowman, 2012).

\subsection{Discussion}

The analysis of the three case studies showed that the three companies faced problems in emerging markets and altered their practices, to overcome them. The main findings are discussed below:

IKEA entered the Chinese market using its global marketing strategy and the same format of its stores. After a better examination of the environment of the Chinese market, the company changed its target groups, focusing on little emperors, reduced its prices, started manufacturing its products in China, in order to develop relations with local companies and reduce its costs, it adapted its stores and advertisements to fit the Chinese culture and the habits of the consumers (Burt et al., 2008; Miller, 2004; PWC, 2009).

The above changes were made, after the company examined the Chinese environment and its internal environment more thoroughly. This analysis is presented below (Table 5.1):

Table 5. 1: SWOT analysis - IKEA

\begin{tabular}{|l|l|}
\hline SWOT analysis for IKEA \\
\hline Strengths & Weaknesses \\
\hline Leader in home furniture sector (Burt et al., & $\begin{array}{l}\text { Considered to be expensive in some countries } \\
\text { (Miller, 2004) }\end{array}$ \\
Exp) & $\begin{array}{l}\text { Copying of its products (Burt et al., 2008) } \\
\text { 2008) }\end{array}$ \\
Same product, image, promotion - standardization & quality (PWC, 2009) \\
(Burt et al., 2008) & \\
Effective supply chain network (PWC, 2009) & \\
Good relations with suppliers (Tarnoskaya et al., & \\
2007) & \\
Low prices (Burt et al., 2008) & \\
Good financial position (Forbes, 2015) & \\
Well-known brand (Forbes, 2015) & \\
\hline
\end{tabular}




\begin{tabular}{|c|c|}
\hline $\begin{array}{l}\text { Joint ventures and collaboration, when needed } \\
\text { (Twarowska \& Kakol, 2013) }\end{array}$ & \\
\hline Opportunities & Threats \\
\hline $\begin{array}{l}\text { Increasing population in emerging markets, } \\
\text { such as China (Burt et al., 2008) } \\
\text { Generation of One Child is impulsive and like } \\
\text { western homes (Burt et al., 2008) } \\
\text { Increased interest for home decorating (Burt et al., } \\
\text { 2008) } \\
\text { Market growth in China (Burt et al., 2008) }\end{array}$ & $\begin{array}{l}\text { Low responsiveness in emerging countries } \\
\text { (Treadgold, 1991) } \\
\text { Lower income in emerging countries (Burt et al., } \\
\text { 2008) } \\
\text { High import taxes in China (Burt et al., 2008) } \\
\text { Consumers without cars can't reach the stores } \\
\text { (Burt et al., 2008) } \\
\text { Different culture, language, taste in China and } \\
\text { other emerging markets }\end{array}$ \\
\hline
\end{tabular}

Coca Cola had problems when it entered the Indian market, as it used aggressive strategies (introducing standard products with standardized marketing strategies (Taneja et al., 2012)) with no relevance to the local conditions. As its standardized global approach proved ineffective, the company adopted a glocal strategy. It tried to come closer to Indian consumers by using Bollywood stars in its advertisements, organizing local promotion and communication actions and it constructed infrastructure, in order to improve its reputation in the market (Mukherjee, 2008; Taneja, 2012; Jaganathan, 2013; Twarowska \& Kakol, 2013; Svensson, 2001). The company's SWOT analysis is shown below (Table 5.2):

Table 5. 2: SWOT analysis - Coca Cola

\begin{tabular}{|c|c|}
\hline \multicolumn{2}{|l|}{ SWOT analysis for Coca Cola } \\
\hline Strengths & Weaknesses \\
\hline $\begin{array}{l}\text { Leader of the beverage market (Forbes, 2015) } \\
\text { Great profits (Forbes, 2015) } \\
\text { Global brand recognition (Forbes, 2015) } \\
\text { Iconic product of high quality (Gomez, 2012) } \\
\text { Corporate social responsibility (Gomez, 2012) } \\
\text { Committed top management (Fernandes, 2013) } \\
\text { New plants in India (Mukherjee, et al. 2008) } \\
\text { Risk management framework (Bowman, 2012) }\end{array}$ & $\begin{array}{l}\text { Too aggressive strategies in emerging markets } \\
\text { (Taneja et al., 2012) } \\
\text { Negative brand image in India (Mukherjee, } \\
\text { 2008) } \\
\text { Ego didn't let Coca Cola form an appropriate } \\
\text { strategy for India (Jaganathan, 2013) } \\
\text { Global communications don't fit all markets } \\
\text { (Taneja, 2012) }\end{array}$ \\
\hline Opportunities & Threats \\
\hline $\begin{array}{l}\text { Research and development unit in China (Gomez, } \\
\text { 2012) } \\
\text { Local recruitments can offer new capabilities } \\
\text { (Fernandes, 2013) } \\
\text { Market size and demographic growth in India } \\
\text { Increase in incomes }\end{array}$ & $\begin{array}{l}\text { Different culture in India (Twarowska \& Kakol, } \\
\text { 2013) } \\
\text { Need for a glocal strategy (Svensson, 2001) } \\
\text { Political factors, as government pressure made the } \\
\text { company leave India in } 1993 \text { (Moye, 2013) }\end{array}$ \\
\hline
\end{tabular}

Kellogg's entered the Indian market using the same marketing mix it used in developed countries, although the culture and nutritional habits in India were different. The company tried to change breakfast habits of Indian consumers, by positioning its products as healthier in relation to traditional breakfast. This approach was too standardized and Indian consumers felt insulted by the company's claim the traditional breakfast they made was not good for their family. In order for Kellogg's to be more likeable by Indian consumers, it adapted to the Indian culture and habits on breakfast. So, it developed new products, especially for India, which were more similar to the local flavors and tastes. Production was localized and local workers were recruited, while some of the raw materials were bought by local suppliers (Shukla, 2011; aneja, 2012; Fernandes, 2013). The SWOT analysis of this company in relation to the Indian market are shown in the following table (Table 5.3):

Table 5. 3: SWOT analysis Kellogg's

\begin{tabular}{|l|l|}
\hline SWOT analysis for Kellogg's \\
\hline Strengths & Weaknesses \\
\hline $\begin{array}{l}\text { One of the most lovable brands in the world } \\
\text { (Forbes, 2015) }\end{array}$ & $\begin{array}{l}\text { Decreasing profitability in Asia (Forbes, } \\
2015)\end{array}$ \\
\hline
\end{tabular}




\begin{tabular}{|c|c|}
\hline $\begin{array}{l}\text { Good financial position (Forbes, 2015) } \\
\text { Leader in cereal market (Kellogg, 2014) } \\
\text { New plants (Bhushan, 2008) } \\
\text { New product development for countries with } \\
\text { different culture (Bhushan, 2012) } \\
\text { Risk management framework (Kellogg, 2014) }\end{array}$ & $\begin{array}{l}\text { Products difficult to adopt in other countries } \\
\text { (Shukla, 2011) } \\
\text { Expensive products (Shukla, 2011) } \\
\text { High foreign currency risk and interest rate risk } \\
\text { (Kellogg, 2014) }\end{array}$ \\
\hline Opportunities & Threats \\
\hline $\begin{array}{l}\text { Segment with potentials in India due to little } \\
\text { penetration (Anand, 2014) } \\
\text { Market growth in India (Anand, 2014) }\end{array}$ & $\begin{array}{l}\text { Different breakfast habits in emerging } \\
\text { countries (Taneja, 2012; Fernandes, 2013) } \\
\text { Local competitors in emerging countries increase } \\
\text { their power (Anand, 2014) }\end{array}$ \\
\hline
\end{tabular}

So, as it may be seen, the three companies changed their practices, so as to fit the environment of the country, thus, combining a local and a global strategy. This combination can also be called Glocal. Moreover, all the three companies pay special attention to risk management, and they have designed a risk management framework, although Kellogg's Project K seems to be more holistic.

Referring to the environment of the two emerging countries a PEST analysis is useful to be conducted, as the literature review indicates the importance of the environmental audit (Jones \& Hill 1992; Bowman \& Faulkner, 1996). This analysis is shown below (Table 5.4):

\begin{tabular}{|c|c|}
\hline Political factors & Economic factors \\
\hline $\begin{array}{l}\text { Government pressure on foreign companies, } \\
\text { especially in India (Moye, 2013) } \\
\text { There were laws for One Child in China, but they } \\
\text { are no longer valid (Burt et al., 2008) }\end{array}$ & $\begin{array}{l}\text { Market growth in India (Anand, 2014) and China } \\
\text { (Burt et al., 2008) } \\
\text { Market size } \\
\text { Increasing population (Burt et al., 2008) } \\
\text { Lower income (Burt et al., 2008) } \\
\text { High import taxes in China (Burt et al., 2008) } \\
\text { Increase in incomes }\end{array}$ \\
\hline Social factors & Technological factors \\
\hline $\begin{array}{l}\text { Different consuming habits and interests, such } \\
\text { as nutrition (Taneja, 2012; Fernandes, 2013), use } \\
\text { of cars (Burt et al., 2008) etc. } \\
\text { Different culture and language (Twarowska \& } \\
\text { Kakol, 2013) } \\
\text { Demographic growth } \\
\text { Increase in western habits (Burt et al., 2008) } \\
\text { Local recruitments can offer new capabilities } \\
\text { (Fernandes, 2013) }\end{array}$ & $\begin{array}{l}\text { Research and development unit in China (Gomez, } \\
\text { 2012) }\end{array}$ \\
\hline
\end{tabular}

\section{Conclusion}

The study stated the practices used by global companies, in order to enter emerging markets. According to the presentation of the companies, the main steps that should be followed are environmental audit, market selection and market entry. The environment has a critical role for internationalization decisions. They are not examined in the case of the companies The market selection is the next step. The organization has to decide which markets to enter, which strategy to use in each one, whether the product or other parts of the marketing mix need to be changed and so forth (Rahman, 2003; Johnson et al., 2008; O'Farrel \& Wood, 1994). Market entry is the third step. The company has to make significant and risky decisions, as there are numerous entry strategies (Sarkar \& Cavusgil, 1996; Hill, 2007). In order for an organization to make up its mind for the market entry it will implement, it has to make two main decisions, the location and the mode of control (Hill et al., 1990). After making the above decisions, global companies have to design the competitive strategy they will implement in the market they entered. According to Porter (1980) the three generic strategies are cost leadership, differentiation and focus strategy. But, even after these decisions are made, there are still difficulties that should be addressed in order for the company to achieve, so there was a need for more specific practices that should be implemented.

The study emphasized on the analysis of effective practices for entering emerging markets. Many multinational companies cannot develop successful strategies in emerging markets, as they attempt to implement their previous 
strategy (Khanna et al., 2005). But, emerging markets have significantly different prevailing conditions. Multinational companies cannot avoid emerging markets, as they have more positive prospects that developed countries, and a very numerous population (Deloitte, 2014). So, companies have to implement effective global strategies for emerging markets, with the following features:

- Engagement with local communities for recruitment and collaboration (Deloitte, 2014).

- Examine both macro-environmental factors and market factors (Khanna et al., 2005)

- External partnerships and alliances (Deloitte, 2014; UK Trade \& Investment, 2010).

- Address social impact issues (Deloitte, 2014).

- Manage supply chain challenges (Deloitte, 2014).

- Companies have to adapt to the local environment (Johansen, 2014; Khanna et al., 2005; Deloitte Consulting, 2011; Boston Consulting Group, 2013)

- Companies have to understand the preferences of customers in each market and design an appropriate strategy (Deloitte Consulting, 2011)

- Companies have to establish company-owned production, service, distribution, $R \& D$, and other operations (Deloitte Consulting, 2011)

- $\quad$ Top management support (BCG, 2013)

- Recruit local talents (BCG, 2013).

- Companies should have a broad range of capabilities (BCG, 2013).

- Use glocal strategy (Taneja et al., 2012)

From the above findings, it is clear that companies that aim to succeed in emerging markets; have to understand the local preferences and culture, by conducting a detailed environmental analysis (Rahman, 2003; Johnson et al., 2008; O'Farrel \& Wood, 1994). After they have a clear view of the opportunities and challenges they have to face, they have to form their strategy for the market entry and to adapt their operations and strategy to fit their new environment (Sarkar \& Cavusgil, 1996; Hill, 2007).

Another issue that was addressed in the study is risk management in global companies. Companies expanding in foreign markets must adapt their risk practices. For example, the macro-environment may change unexpectedly, so the global company has to immediately re-adjust its risk management strategy (PwC, 2012; 2012a). They have to predict new risks, the possibility of each risk to happen and to schedule new ways to face them. Companies have to invest money and time to improve constantly their risk management systems, so as to avoid losses for unexpected risks that may have a negative impact to their reputation as well, apart from an economic impact. Global companies seem to realize the increased need for risk management, as seen in many surveys (Economist Intelligence Unit, 2006), but the majority of companies do not yet have an effective risk management framework (Economist Intelligence Unit, 2006; Ernst \& Young, 2007; Harvard Business Review Analytic Services, 2011; KPMG, 2011). Another cause that increased the attention given to risk management is the financial crisis of 2008, which changed unexpectedly the conditions in many countries at the same time (Harvard Business Review Analytic Services, 2011). Top executives of most companies have realized the rapidly changing nature of the environment, but the creation of an effective risk management system requires abilities and time. But, it is necessary for each company to have a developed risk management system before it enters a new market or before a new crisis affects it.

The case study analysis examined whether real companies use the same practices as the ones found in the theoretical context. The first company that was examined is IKEA. IKEA has the principle to operate similarly and have the same image and culture in all countries. As seen in the above analysis, IKEA had to localize its practices to enter the new market and fit the local environment. The strategy to enter the market is selected after examining the country's environment, but before entering the market. However, IKEA had to change its strategy more than expected, a fact that also affected its culture. The culture of the company in the Chinese market is differentiated from the mother company, although the central values of the organization remain the same. The second company was Kellogg's. Kellogg's is one of the best known global brands and the world's leader in cereals. Its breakfast cereals are being sold in 160 countries. But, despite its worldwide success, Kellogg's faced problems when entered the Indian market. Finally, Coca Cola faced similar products when it entered the Indian market. From the cases studies, some practices came out to be successful when entering an emerging market with a different culture, thus answering the first research question ("What practices are followed by the selected 
companies to become active in emerging markets?"). These practices used by the companies of the study are the following:

- Use of a glocal strategy that fits the emerging market, but keeps the main characteristics of the global brand.

- Different pricing, as the macro-economic environment is different and wages are lower in the emerging market

- Manufacture the products and infrastructure in the emerging market.

- Advertisements that fit the local attitudes.

- Different product mix, with new products, more suitable for the new market.

These results may seem obvious for most of the companies trying to expand their activities abroad, but some of the largest brands in the world would expect to be more welcome in new countries, without any significant changes in the way they function. For example, Kellogg's expected to have a more enthusiastic reception of its products, as they represent a different way of life. Moreover, Coca Cola believed that its brand is connected to a way of living, and people from developing countries would like to adopt this way of living in order to feel that they are part of the western culture. These beliefs are shown to be untrue and the examined companies were obliged to change even their product mix to enter these markets, in a more severe way. The analysis contributed to the presentation of the fact that very large and successful companies may sometimes be blinded by their ego and not realize the extensive changes they have to make, in order to be accepted in a country with a different environment.

So as to answer the second research question ("How do the selected companies manage the risks of entering an emerging economy?"), the risk management system of the three companies was analyzed. It came out that all of them have a risk management procedure. IKEA has created a responsible supply chain program. Kellogg's has launched Project K, which will improve efficiency and effectiveness and help risk management. Coca Cola has designed a specific risk management process which focuses on identification of risks and uses data mining and analytics. This finding is in contrast with the findings of the literature review, as most studies found out that most companies do not have specific risk management systems.

The analysis also showed the factors that should be taken into consideration, when entering a new market (Research question 3: Which are the factors that should be taken into consideration when entering an emerging market?). The case studies showed that all three companies had to have a deep knowledge of the country they wanted to enter, after conducting an analysis of the environment, also taking into consideration the cultural differences. It came out that political, economical, social and cultural factors are very important.

Finally, the risks and challenges companies deal with when entering emerging markets and how globalization and the characteristics of the markets increase or minimize these risks and challenges (Research question 4). The main opportunities are found to be the market size, market growth, the changing habits of the population and globalization, which makes expansion easier. On the other hand, there are threats as well, coming from the market environment. The most important ones are found to be the political environment (in Coca Cola's case), and most importantly, the social-cultural environment, as consumers in these markets have different habits, income and way of life, which make the buying decision process more complicated. So, globalization makes the companies more willing to expand to emerging markets, but the market characteristics tend to increase the challenges.

The overall conclusion that can be made is that no matter how successful a company may be, it cannot not use the same practices and strategies in every market. In order for the company to adjust its practices and strategy in emerging markets, it has to have a good knowledge of the market, after having conducted an environmental analysis. The above conclusions are in agreement with the findings of the literature review, which indicate the significance of the environmental analysis and the need for strategic fit to the local market (Deloitte, 2014; Johansen, 2014; Khanna et al., 2005; Deloitte Consulting, 2011; Boston Consulting Group, 2013).

\subsection{Limitations of the Study}

The analysis took place using a case study approach. This research method is qualitative and it only examines one or a few cases in their real environment. But, the specific methodology has limitations. The most important one is the fact that the findings cannot easily be generalized (Dul \& Hak, 2008). Another weakness of the research is the lack of primary data, which could have be obtained if interviews with executive were conducted. The data would be even more useful if the managers were from different countries.

\subsection{Recommendations for Further Research}

In order the research conclusions to be generalized, a further study could take place applying an empirical study approach for data collection, and following a quantitative approach of data analysis in order strategic trends to be 
defined and information to be provided regarding interrelation of factors that influence the types and size of risks companies face when expand abroad.

\section{References}

Anand, N. (2014). Kellogg bets on India-centric innovation to grow market share. DNA India, January 22. Retrieved from http://www.dnaindia.com/money/interview-kellogg-bets-on-india-centricinnovation-to-grow-market-share-1954979 (assessed at 25 May 2015)

Ang, S. H., Leong, S. M., \& Kotler, P. (2000). The Asian apocalypse: crisis marketing for consumer and businesses. Long Range Planning, 33, 97-119. https://doi.org/10.1016/S0024-6301(99)00100-4

Anıl, I., Cakir, O., \& Canel, C. (2010). A comparison of inward and outward foreign direct investment determinants in Turkey. Southeast Decision Sciences Institute Fortieth Annual Conference Proceedings 528-542, Wilmington, NC.

Bailey, W., \& Chung, P. Y. (2004). Exchange rate fluctuations, political risk and stock returns: Some evidence from an emerging market, Journal of Financial and Quantitative Analysis, 30(4), 541-561. https://doi.org/10.2307/2331276

Ball, D. A., McCulloch, W. H. Jr., Frantz, P. L., Geringer, J. M., \& Minor, M. S. (2004). International Business: The Challenge of Global Competition, New York: McGraw-Hill.

Bartlett, C., \& Beamish, P. (2010). Transnational management: Text, cases \& readings in cross-border management. New York: McGraw-Hill.

Bhushan, R. (2012). Kellogg India to take a second shot at localizing its India portfolio. The Economic Times, October 19. Retrieved May 25, 2015, from http://articles.economictimes.indiatimes.com/2012-10-19/news/34584530_1_kellogg-indialocalised-variants-nimbooz

Bhushan, R. (2012). Kellogg's bets on localization to beat others. The Economic Times, July 3. Retrieved May 25, 2015, from http://articles.economictimes.indiatimes.com/2008-0703/news/27707438_1_cereal-kellogg-india-muesli

Boston Consulting Group. (2013). Playing to win in emerging markets. The Boston Consulting Group, September. Retrieved May 14, 2015, from http://www.bcg.de/documents/file143337.pdf

Bowman, C., \& Faulkner, D. (1996). The Essence of Competitive Strategy, London: Prentice Hall. https://doi.org/10.1007/978-1-349-24381-5_3

Bowman, R. J. (2012). Risk management: Making the right choices. Supply Chain Brain, October 29. Retrieved April 5, 2015, from http://www.supplychainbrain.com/

Brouthers, K. D., \& Hennart, J. F. (2007). Boundaries of the firms: Insights from international entry mode research., Journal of Management, 33(3), 395-425. https://doi.org/10.1177/0149206307300817

Buckley, P. J., \& Casson, M. C. (1998). Analyzing Foreign market entry strategies: Extending the internalization approach. Journal of International Business Studies, 29(3), 539-561. https://doi.org/10.1057/palgrave.jibs.8490006

Burt, S., Johansson, U., \& Thelander, A. (2008). Standardized marketing strategies in retailing? IKEA's marketing strategies in China, Sweden and the UK. In proceedings of $1^{\text {st }}$ Nordic Retail and Wholesale Conference, November 6-7, 2008, Stockholm, Sweden.

Deloitte Consulting. (2011). Fortresses and foothold: Emerging market growth strategies, practices and outlook. Retrieved April 5, 2015, from http://www2.deloitte.com/us/en/pages/strategy/articles/emerging-marketgrowth-strategies-practices-and-outlook.html

Deloitte. (2013). Exploring strategic risk. Retrieved April 2, 2015, from http://deloitte.wsj.com/

Deloitte. (2014). Deloitte's globalization survey: Preparing for the next wave of globalization, Deloitte University Press.

Denzin, N. K., \& Lincoln, Y. S. (2000). Handbook of Qualitative Research (2nd ed). Thousand Oaks, CA: Sage.

Dikova, D., \& van Witteloostuijn, A. (2007). Foreign direct investment mode choice: Entry and establishment modes in transition economies. Journal of International Business Studies, 38(6), 1013-1033. https://doi.org/10.1057/palgrave.jibs. 8400297 
Dow, D. (2000). A Note on Psychological Distance and Export Market Selection. Journal of International Marketing, 8(1), 51-64. https://doi.org/10.1509/jimk.8.1.51.19563

Dufour, S., \& Fortin, D. (1992). Annotated bibliography on case study method. Current Sociology, 40(1), 167200. https://doi.org/10.1177/001139292040001011

Dul, J., \& Hak, T. (2008). Case study methodology in business research. Oxford: Butterworth-Heinemann. https://doi.org/10.4324/9780080552194

Dunning H. J. (1980). Toward an eclectic theory of international production: some empirical tests. Journal of International Business Studies, 11(1), 9-31. https://doi.org/10.1057/palgrave.jibs.8490593

Ernst \& Young. (2007). Risk management in emerging markets. London: Ernst \& Young. Retrieved from www.emergy.at

Fernandes, S. (2013). A case study on Indian companies and global companies' entry in foreign market - An analysis of Glocalization strategy. Journal of Business Management \& Social Sciences Research, 2(1), 30-39.

Floyd, D. (1996). Foreign direct investment in Poland: Is low cost labor really the sole determinant? Economic, 2 , 29-39.

Forbes. (2015). The world's most valuable brands. May 13. Retrieved May 25, 2015, from $\mathrm{http} / / / \mathrm{www}$.forbes.com/powerful-brands/

Ghoshal, S. (1987). Global strategy: An organizing framework. Strategic Management Journal, 8, 425-440. https://doi.org/10.1002/smj.4250080503

Gomez, M. B. B. (2012). Coca-Cola: International business strategy for globalization. In proceedings of International Trade \& Academic Research Conference, November, 7-8, 2012, London, UK.

Grewal, R., \& Tansuhaj, P. (2001). Building organizational capabilities for managing economic crisis: The role of market orientation and strategic flexibility. Journal of Marketing, 65(April), 67-80. https://doi.org/10.1509/jmkg.65.2.67.18259

Hallikas, J., Karvonen, I., Pulkkinen, U., Virolainen, V. M., \& Tuominen, M. (2004). Risk management processes in supplier networks. International Journal of Production Economics, 90(1), 47-58. https://doi.org/10.1016/j.ijpe.2004.02.007

Hamel, G., \& Prahalad, C. K. (1986). Do you already have a global strategy? Harvard Business Review, JulyAugust, 139-148.

Hansegart, J. (2014). IKEA sales boosted by China. The Wall Street Journal, September 9. Retrieved May 25, 2015, from http://www.wsj.com/articles/ikea-sales-boosted-by-china-1410246927

Hartley, J. (1994). Case studies in organizational research. In C. Cassell, \& G. Symon (Eds.), Qualitative methods in organizational research: A practical guide (pp. 208-229). London: Sage.

Harvard Business Review Analytic Services. (2011). Risk management in a time of global uncertainty. Zurich: Harvard Business Review. Retrieved May 18, 2015, from https://hbr.org/resources/pdfs/tools/17036_HBR_Zurich_Report_final_Dec2011.pdf

Henisz, W. J., \& Zelner, B. A. (2010). Hidden risks in emerging markets. Harvard Business Review, April, 1-8.

Hill, C., Hwang, P., \& Kim, W. C. (1990). An eclectic theory of the choice of international entry mode. Strategic Management Journal, 11(2), 117-128. https://doi.org/10.1002/smj.4250110204

Hill, C. W. L. (2007). International business: competing in the global marketplace (6th ed.). Boston, Mass: McGraw-Hill/Irwin.

Hill, J. S. (2009). International business: Managing globalization. Sage publications.

Hitt, M. A., Ireland, D. R., \& Hoskisson, R. E. (2009). Strategic management: Competitiveness and Globalization (Concepts and cases). Mason, OH: Cengage Learning.

Hopkin, P. (2014). Fundamentals of risk management. London: The Institute of Risk Management.

Iacono, J. C., Brown, A., \& Holtham, C. (2011). The use of case study method in theory testing: The example of steel e-marketplaces. Journal of Business Research Methods, 9(1), 57-65.

Isobe, T., Makino, S., \& Montgomery, D. B. (2000). Resource commitment, entry timing and market performance of foreign direct investments in emerging economies: The case of Japanese international joint ventures in China. Academy of Management Journal, 43(3), 468-484. https://doi.org/10.2307/1556405 
Jaganathan, R. (2013). How the MNC ego blinded Kellogg's, Coke and Unilever in India. F Business, December 27. Retrieved May 20, 2015, from http://www.firstpost.com/business/how-the-mnc-egoblinded-kelloggs-coke-and-unilever-in-india-1309483.html

Johansen, D. (2014). Strategic logic and marketing resources: A case analysis approach to emerging market success. Journal of International Business \& Cultural Studies, 9, 1-18.

Johansson, R. (2003). Case study methodology. In proceedings of the International Conference "Methodologies in Housing Research" organized by the Royal Institute of Technology in cooperation with the International Association of People-Environment Studies, September, 22-24, Stockholm, Sweden.

Johnson, G., Scholes, K., \& Whittington, R. (2008). Exploring Corporate Strategy (8th ed.) London: Financial Times, Prentice Hall.

Jones, G. R., \& Hill, C.W. (1992). Strategic Management: An Integrated Approach, Boston: Houghton Mifflin Company: 28-33.

Kasimoglu, M. (2000). Survival strategies for companies in global business world - A case study. Silesian University in Opava.

Kellogg Company. (2015). 2014 Annual Report. Letter to shareowners and SEC Form 10-K, January 3. Retrieved April 1, 2015, from http://investor.kelloggs.com/investor-relations/annual-reports/default.aspx

Kellogg's Company. (2013). History of Kellogg's. Retrieved April 2, 2015, from http://www.kelloggs.ca/en_CA/our-history.html

Kellogg's Company. (2013). Our Values. Retrieved April 1, 2015, from http://www.kelloggcompany.com/en_US/our-values.html

Khanna, T., \& Palepu, K. G. (2006). Emerging giants: Building world-class companies in developing countries. Harvard Business Review, 84(10), 60-69.

Khanna, T., Palepu, K. G., \& Sinha, J., (2005). Strategies that fit emerging markets. Harvard Business Review, June.

Kirtis, A. K., \& Karahan, F. (2011). To be or not to be in social media arena as the most cost-efficient marketing strategy after the global recession, Procedia Social and Behavioral Sciences, 24, 260-268. https://doi.org/10.1016/j.sbspro.2011.09.083

Koch, A. G. (2001). Factors influencing market and entry mode selection: developing the MEMS model. Marketing Intelligence \& Planning, 19(5), 351 - 361. https://doi.org/10.1108/EUM0000000005652

Koksal, M. H., \& Ozgul, E. (2007). The relationship between marketing strategies and performance in an economic crisis. Marketing Intelligence and Planning, 25(4), 326-342. https://doi.org/10.1108/02634500710754574

KPMG. (2011). Risk management: A driver of enterprise value in the emerging environment. Retrieved April 5 , 2015, from at: www.kpmg.com

Kumar, V., Stam, A., \& Joachimsthaler, E. A. (1994). An Interactive Multicriteria Approach to Identifying Potential Foreign Markets. Journal of International Marketing, 2(1), 29-52. https://doi.org/10.1177/1069031X9400200103

Kwon, Y. C., \& Konopa, L. J. (1993). Impact of Host Country Market Characteristics on the Choice of Foreign Market Entry Mode. International Marketing Review, 10(2), 343-350. https://doi.org/10.1108/02651339310032552

Laitinen, E. K. (2000). Long-term success of adaptation strategies: evidence from Finnish companies. Long Range Planning, 33, 805-830. https://doi.org/10.1016/S0024-6301(00)00088-1

Lassar, W., Haar, J., Montalvo, R., \& Hulser, L. (2010). Determinants of strategic risk management in emerging markets supply chains: The case of Mexico. Journal of Economics, Finance and Administrative Science, 125140.

Lavastre, O., Gunasekaran, A., \& Spalazani, A. (2012). Supply chain management in French companies. Decision Support Systems, 52, 828-838. https://doi.org/10.1016/j.dss.2011.11.017

Lee, S. H., \& Makhija, M. (2009). Flexibility in internationalization: Is it valuable during an economic crisis? Strategic Management Journal, 30, 537-555. https://doi.org/10.1002/smj.742

Lee, S. H., Beamish, P. W., Lee, H. U., \& Park, J. H. (2009). Strategic choice during economic crisis: Domestic 
market position, organizational capabilities and export flexibility. Journal of World Business, 44, 1-15. https://doi.org/10.1016/j.jwb.2008.03.015

London, T., \& Hart, S. L. (2004). Reinventing strategies for emerging markets: beyond the transnational model, Journal of International Business Studies, 35, 350-370. https://doi.org/10.1057/palgrave.jibs.8400099

Luo, Y. (2007). From foreign investors to strategic insiders: Shifting parameters, prescriptions and paradigms for MNCs in China. Journal of World Business, 42(1), 14-34. https://doi.org/10.1016/j.jwb.2006.08.009

Malhotra, S., Sivakumar, K., \& Zhu, P. C. (2009). Distance factors and target market selection: the moderating effect of market potential. International Marketing Review, 26(6), 651-673. https://doi.org/10.1108/02651330911001332

March, J. G. (1981). Footnotes on organizational change. Administrative Science Quarterly, 26, 563-597. https://doi.org/10.2307/2392340

Martin, C., Carlos, M., Omera, K., \& Oznur, Y. (2011). Approaches to managing global sourcing risk. Supply Chain Management: An International Journal, 16(2), 67-81. https://doi.org/10.1108/13598541111115338

Maynard, M., \& Tian, Y. (2004). Between global and local: content analysis of the Chinese websites of the 100 top global brands, Public Relations Review, 20(3), 285-291. https://doi.org/10.1016/j.pubrev.2004.04.003

Meyer, K., \& Nguyen, H. V. (2005). Foreign investment strategies and sub-national institutions in emerging markets: Evidence from Vietnam, Journal of Management Studies, 42(1), 63-93. https://doi.org/10.1111/j.1467-6486.2005.00489.x

Meyer, K. E. (1995). Direct Foreign investment in eastern Europe: the role of labour costs. Comparative Economic Studies, 37, 69-88. https://doi.org/10.1057/ces.1995.42

Meyer, K. E., Estrin, S., Bhaumik, S. K., \& Peng, M. W. (2009). Institutions, resources, and entry strategies in emerging economies. Strategic Management Journal, 30(1), 61-80. https://doi.org/10.1002/smj.720

Meyer, K., Estrin, S., Bhaumik, S. K., \& Peng, M. W. (2009). Institutions, resources and entry strategies in emerging economies. Strategic Management Journal, 30(1), 61-80. https://doi.org/10.1002/smj.720

Miller, P. M. (2004). IKEA with Chinese characteristics, The China Business Review, July 1. Retrieved May 25, 2015, from http://www.chinabusinessreview.com/ikea-with-chinese-characteristics/

Moye, J. (2013). 20 Years later: A look back at Coke's dramatic 1993 return to India, December 6. Retrieved April 6, 2015, from http://www.coca-colacompany.com/

Mpourantas, D. (2002). Management. Athens: Benou Publishing (in Greek).

O'Farrell, P. N., \& Wood, P. A. (1994). International Market Selection by Business Service Firms: Key conceptual and methodological issues. International Business Review, 3(3), 243-261. https://doi.org/10.1016/09695931(94)90004-3

Olsson, C. (2002). Risk management in emerging markets: How to survive and prosper. London: Financial Times/ Prentice Hall.

Pan, Y., Li, S., \& Tse, D. K. (1999). The impact of order and mode of market entry on profitability and market share. Journal of International Business Studies, 30(1), 81-103. https://doi.org/10.1057/palgrave.jibs.8490061

Parsa, H. G., \& Kwansa, F. A. (2010). Quick service restaurants franchising and multi-unit chain management. New York: Routledge.

Pearce, J. A., \& Michael, S. C. (2006). Strategies to prevent economic recessions from causing business failure. Business Horizons, 49, 201-209. https://doi.org/10.1016/j.bushor.2005.08.008

Platt, J. (1992). Case study in American methodological thought. Current Sociology, 40, 17-48. https://doi.org/10.1177/001139292040001004

Porter, M. E. (1980). Competitive strategy. New York: Free Press.

Prahalad, C. K., \& Bhattacharyya, H. (2011). How to be a truly global company. Strategy \& Business, 64, 1-8.

Prahalad, C. K. (2006). The Fortune at the Bottom of the Pyramid. New Jersey: Wharton School Publishing.

Prahalad, K., \& Hamel, G. (1990). The Core Competence of Organization. Harvard Business Review, 68(3), 7991. 
PricewaterhouseCoopers. (2009). Seizing opportunity: Linking risk and performance, United States of America.

PricewaterhouseCoopers. (2012). Risk in review. Coping with the unknown: risk management strategies for an uncertain world. August. Retrieved May 21, 2015, from http://www.pwc.com/us/en/risk-assuranceservices/publications/assets/pwc-risk-in-review-aug-2012.pdf

PricewaterhouseCoopers (2012). Delivering results: Growth and values in a volatile world. $15^{\text {th }}$ Annual Global CEO Survey.

Rahman, S. H. (2003). Modeling of international market selection process: a qualitative study of successful Australian international businesses. Qualitative market research: An international Journal, 6(2), 119-132. https://doi.org/10.1108/13522750310470127

Ramamurti, R. (2012). What is really different about emerging market multinationals? Global Strategy Journal, 2, 41-47. https://doi.org/10.1002/gsj.1025

Reuer, J., \& Leiblein, M. (2000). Downside risk implications of multinational and international joint ventures. Academy of Management Journal, 43(2), 203-214.

Richie, J., \& Lewis, J. (2003). Qualitative research practice. London: Sage Publications. https://doi.org/10.2307/1556377

Root, F. R. (1994). Entry Strategies for International Markets. New York: Lexington.

Rugman, A. M., \& Varbeke, A. (2004). A perspective on regional and global strategies of multinational enterprises. Journal of International Business Studies, 35, 3-18. https://doi.org/10.1057/palgrave.jibs.8400073

Rumelt, R. P. (1991). How much does industry matter? Strategic Management Journal, 12(3), 167-185. https://doi.org/10.1002/smj.4250120302

Ruzzier, M., Hisrich, R. D., \& Antoncic, B. (2006). SME internationalization research: past, present and future. Journal of Small Business and Enterprise Development, 13(4), 476-497. https://doi.org/10.1108/14626000610705705

Sarkar, M., \& Cavusgil, S. T. (1996). Trends in international business thought and literature: A review Management Decision of international market entry mode research: Integrations and synstudy. The International Executive, 38(6), 825-847. https://doi.org/10.1002/tie.5060380608

Shukla, A. (2011). FMCG firms eye health food market. Business Today, October 8. Retrieved April 1, 2015, from http://businesstoday.intoday.in/story/fmcg-firms-eye-health-food-market/1/19180.html

Singh, K., \& Yip, S. G. (2000). Strategic lessons from the Asian crisis. Long Range Planning, 33, 706-729. https://doi.org/10.1016/S0024-6301(00)00078-9

Solberg, C. A., \& Durrieu, F. (2006). Strategy development in international markets. A two tier approach. In proceedings of Annual IMP Conference, Milano, September.

Stake, R. (2000). Case studies. In N. Denzin, \& Y. Lincoln (Eds.), Handbook of Qualitative Research, 435-454. Thousand Oaks: Sage.

Svensson, G. (2001). Glocalization" of business activities: a "glocal strategy" approach. Management Decision, 39(1), 6-18. https://doi.org/10.1108/EUM0000000005403

Taneja, G., Girdhar, R., \& Gupta, N. (2012). Marketing strategies of global brands in Indian markets. Journal of Arts, Science \& Commerce, 3(3), 71-78.

Tang, C. Y., \& Tikoo, S. (1999). Operational flexibility and market valuation of earnings. Strategic Management Journal, 20(8), 749-761. https://doi.org/10.1002/(SICI)1097-0266(199908)20:8<749::AIDSMJ53>3.0.CO;2-L

Tarnoskaya, V., Ghauri, P. N., \& Elg, U. (2007). Market driving supplier strategy: IKEA's global sourcing network in two developing markets. In proceedings of Annual IMP Conference, September.

The Economist Intelligence Unit. (2006). Operating risk in emerging markets. London: ACE. Retrieved from $\mathrm{http}: / / w w w . a c e g r o u p . c o m / s e-e n / a s s e t s /$ eiu-ace-operating-risk.pdf

Tripsas, M., \& Gavetti, G. (2000). Capabilities, cognition, and inertia: Evidence from digital imaging. Strategic Management Journal, 21, 1147-1161. https://doi.org/10.1002/1097-0266(200010/11)21:10/11<1147::AIDSMJ128>3.0.CO;2-R

Twarowska, K., \& Kakol, M. (2013). International business strategy. Reasons and forms of expansion into foreign 
markets. In proceedings of Management, Knowledge and Learning International Conference, June, 19-21, Zadar, Croatia.

UK Trade \& Investment, (2010). Great expectations: Doing business in emerging markets. Crown, September.

Vernon, R. (1983). Organizing and institutional responses to international risk. In Herring, R. (Ed.), Managing international risk (pp. 191-216). New York: Cambridge University Press. https://doi.org/10.1017/CBO9780511664601.011

Vissak, T. (2010). Recommendations for using the case study method in international business research. The Qualitative Report, 15(2), 370-388.

Witcher, B. J., \& Chaw, V. S. (2012). Varieties of capitalism and strategic management: Managing performance in multinationals after the global financial crisis. The British Journal of Management, 23(S1), S58-S73. https://doi.org/10.1111/j.1467-8551.2012.00816.x

Wood, V. R., \& Robertson, K. R. (2000). Evaluating international markets: the importance of information by industry, by country of destination, and by type or export transaction. International Marketing Review, 17(1), 34-55. https://doi.org/10.1108/02651330010314704

Wright, M., Filatotchev, I., Hoskisson, R. E., \& Peng, M. W. (2005). Guest editors' introduction: Strategy research in emerging economies: Challenging the conventional wisdom. The Journal of Management Studies, 42(1), 1-33. https://doi.org/10.1111/j.1467-6486.2005.00487.x

Yin, R. (2003). Case study research: Design and methods (3rd ed). Thousand Oaks: Sage.

Zehir, C. (2005). The activation level of crises and the change of strategic targets of enterprises in Turkey during the depression era. Journal of the American Academy of Business, 5(2), 293-299.

Zehir, C. and Savi, F.Z. (2004). A field research about implications of organizational downsizing on employees working for Turkish public banks. Journal of American Academy of Business, 5 (1-2), 343-349.

Zou, S., \& Cavusvil, S. T. (2002). The GMS: a broad conceptualization of global marketing strategy and its effects on firm performance. Journal of Marketing, 66, 40-56. https://doi.org/10.1509/jmkg.66.4.40.18519

\section{Copyrights}

Copyright for this article is retained by the author(s), with first publication rights granted to the journal.

This is an open-access article distributed under the terms and conditions of the Creative Commons Attribution license (http://creativecommons.org/licenses/by/4.0/). 